\title{
Composition, ecology and conservation of the south-Iberian serpentine flora in the context of the Mediterranean basin
}

\author{
Andrés V. Pérez-Latorre, Noelia Hidalgo-Triana* \& Baltasar Cabezudo \\ Departamento de Biología Vegetal (Botánica), Universidad de Málaga, P. O. Box 59, E-29080 Málaga, Spain \\ avperez@uma.es; nhidalgo@uma.es; bcabezudo@uma.es
}

\begin{abstract}
Pérez-Latorre, A.V., Hidalgo-Triana, N. \& Cabezudo, B. 2013. Composition, ecology and conservation of the south-lberian serpentine flora in the context of the Mediterranean basin. Anales Jard. Bot. Madrid 70(1): 62-71.

Peridotite outcrops have special lithological (serpentine) and soil characteristics; they also support an unique flora and vegetation "that clearly differ from that of other soil types. One of the most important peridotite outcrops in the Western Mediterranean Basin is located in Sierra Bermeja (Andalusia, Spain). The establishment of a complete ecological-floristic checklist of serpentinophytes in this area, and a comparison with other serpentine-endemic floras in the Mediterranean Basin, is essential for the assessment, management and conservation of these special areas. The recognition of serpentinophytes was made following six criteria used for floras inhabiting special substrata, . The list of species exclusively or partially found on peridotite comprises 27 taxa with a variable degree of serpentinophily: obligate serpentinophytes (obligate endemics), preferential serpentinophytes (populations located mainly on serpentine) and subserpentinophytes (with some populations located on magnesium-rich substrata). As observed in other Mediterranean outcrops, the number of obligate serpentinophytes increases with the area of the outcrop, and the genera Alyssum, Arenaria, Armeria, Centaurea and Silene were the most frequent. Most of the studied serpentinophytes, except for a few xerothermophilous taxa, present a wide bioclimatic (altitudinal) range and grow in shrublands and pastures in rocky places with shallow soils. As many as $56 \%$ of the serpentinophytes are threatened and, among obligate serpentinophytes, $45 \%$ are categorized as critically endangered or endangered, emphasizing the need for urgent conservation measures on the species and their habitats Based on this checklist, more detailed studies may focus on serpentinophytes for their particular physiology, adaptive traits, functional types, phenology and applications.
\end{abstract}

Keywords: serpentinophytes, peridotite rocks, conservation, ecology, Mediterranean flora, management.

\section{INTRODUCTION}

Peridotites are recognized as one of the most peculiar rock types on Earth, both for their plutonic igneous origin and chemical composition (Roberts \& Proctor, 1992). Serpentine soils originate from this type of rock, and are well known for their physical and chemical anomalies that present a hostile environment for plants (Brooks, 1987). Anomalies such as high $\mathrm{Fe}$ and $\mathrm{Mg}$ contents, a low Ca content, a deficiency of nutrients $(\mathrm{N}, \mathrm{P}, \mathrm{K})$, infertility, toxic concentrations of heavy metals $(\mathrm{Cr}, \mathrm{Ni}, \mathrm{Co}, \mathrm{Va})$, very slow soil development and high xerothermicity characterize these soils (Whittaker, 1954; López González, 1975; Brooks, 1987). Such characteristics make serpentine habitats highly selective for plants and relatively few species, called serpentinophytes or serpentinophilous, are adapted to grow on such a substrate (Rune, 1953; Jeffrey, 1987; Selvi, 2007). Following Kruckeberg (2002), serpentino-

\section{Resumen}

Pérez-Latorre, A.V., Hidalgo-Triana, N. \& Cabezudo, B. 2013. Composición, ecología y conservación de la flora serpentínica suribérica en el contexto de la cuenca mediterránea. Anales Jard. Bot. Madrid 70(1): 62-71 (en inglés).

Las peridotitas muestran especiales características litológicas (serpentinas) y edáficas; lo que condiciona una flora y vegetación original y distinta de los alrededores. Uno de los afloramientos más importantes de la cuenca mediterránea occidental está representado por Sierra Bermeja (Andalucía, España). Es esencial establecer un catálogo florístico-ecológico completo de serpentinófitos y compararlo con otros catálogos de endemismos serpentinícolas en el Mediterráneo, para la ordenación, gestión y conservación en estas áreas particulares. La selección de serpentinófitos se realizó siguiendo seis de los criterios utilizados para floras que habitan sustratos especiales. La lista de especies ligadas total o parcialmente a las peridotitas incluye 27 taxones, con un grado variable de serpentinofilia: serpentinófitos estrictos (endemismos obligados), serpentinófitos preferentes (con poblaciones mayoritariamente sobre peridotitas) y subserpentinófitos (con algunas poblaciones localizadas en substratos ricos en magnesio). Como se observa en otros afloramientos del Mediterráneo, el número de serpentinófitos estrictos aumenta con el área del afloramiento y los géneros Alyssum, Arenaria, Armeria, Centaurea y Silene son los más comunes. La mayoría de serpentinófitos presentan un amplio rango bioclimático altitudinal, excepto algunos xerotermófilos, y casi todos crecen en matorrales y pastizales en lugares rocosos con litosuelos. Un $56 \%$ de los serpentinófitos están amenazados y, entre los serpentinófitos estrictos, un $45 \%$ están catalogados en peligro crítico o en peligro, subrayando la urgente aplicación de medidas sobre las especies y sus hábitats. Tomando este listado de serpentinófitos como base, debe profundizarse en estudios sobre su fisología especial, síndromes, tipos funcionales, fenología y aplicaciones.

Palabras clave: serpentinófitos, peridotitas, conservación, ecología, flora mediterránea, manejo.

phytes can be divided into three categories: a) endemic taxa, linked exclusively to peridotites, b) preferential taxa, whose distribution is mainly associated with peridotite but occasionally found on other substrata and c) taxa living on a variety of substrata but also on peridotite (bodenvag taxa).

Obligate serpentinophytes may have a particular metabolism for avoiding the toxic effect of heavy metals (Roberts \& Proctor, 1992; Brady \& al., 2005). Moreover, some facultative species show a serpentine-morph syndrome, e.g. a complex of morpho-functional adaptations that distinguish the serpentine populations from those living on other substrates (stenophyllous, glabrous, glaucous, macro-rooted plants, plagiotropism and nanism) (Pichi-Sermolli, 1948). The high concentrations of magnesium in serpentine soils allow the presence of a magnesicolous flora that develops equally on serpentine and dolomite rocks (Rivas Goday, 1974; Mota \& al., 2008). Studies on species adapted to this type of serpentine 
ecosystem are considered of great interest for the restoration of contaminated soils, the mining of heavy metals, the study of the evolution in extreme habitats, and in conservation biology surveys (Brady \& al., 2005).

The most important area for obligate serpentinophytes in Europe (with 123 taxa) is situated in the Balkans (Stevanovic $\&$ al., 2003). The westernmost peridotite outcrops in the Mediterranean Basin are situated in the south of the Iberian Peninsula (Andalusia) where they cover a total area of $430 \mathrm{~km}^{2}$ (IGME, 1970 and 1981), with an altitudinal range from 100 to 1500 m occupying three bioclimatic belts (Pérez Latorre \& al., 1998). South-Iberian peridotites have frequently been converted into serpentines by hydrolysis (Yusta \& al., 1985).

The flora and plant communities of Andalusian peridotites have been studied by several authors, including Rivas Goday (1974), López González (1975) and Rivas Goday \& López González (1979). Some species are hyper-accumulators of Ni (Rufo \& al., 2004; Díez-Garretas \& al., 2009) and others show the serpentine-morph syndrome characters described above (López González, 1975; Alados \& al., 1999). Climax forest vegetation in these habitats is characterized by pine (Pinus pinaster Aiton) and fir forest (Abies pinsapo Clemente ex Boiss.) but they are frequently substituted by shrublands because of frequent fires (Cabezudo \& al., 1989; López González, 1975; Pérez Latorre \& al., 1998). Most south-Iberian serpentinophytes and the plant communities where they live are included in the 92/43EU "Habitats" Directive; some of them are also threatened and/or protected. Some of the peridotite outcrops are listed as LIC (Important Areas for European Conservation) and/or regional protected areas (Natural Park, Natural Site) and they are considered as Mediterranean phylogeographic refuges and "hot-spots" for Mediterranean plant diversity (e.g. part of the Serrania de Ronda refugia; Médail \& Diadema, 2009). They are also considered important areas (exceptional category) for threatened Spanish flora (Bañares \& al., 2003). Moreover, peridotite outcrops have a great importance in the phytogeographical scheme of the Iberian Peninsula as they are given the category of sector (Bermejense sector) within the Betica province (Western Mediterranean region) (Nieto \& al., 1991). In an attempt to broaden our knowledge of peridotite plant biology and distribution, the main aims of this work were to: 1 , provide a checklist of the serpentinophytes of the southern Iberian Peninsula; 2, study serpentinophytes as a group in terms of life form, systematic spectrum (families), ecology, phytosociology and threat level; and 3, compare the group of south-Iberian serpentinophytes with other Mediterranean serpentine floras and the flora living on other closely related rocks such as dolomites.

\section{MATERIAL AND METHODS}

\section{Study area}

The main peridotite outcrops in the south of the Iberian Peninsula (Fig. 1) are located in the province of Malaga (Ronda Mountain Range; Fig. 2). The mineralogical composition is characterized by harzburgite, lherzolite, piroxenite and serpentinite. They can be grouped them into four geographical units (Fig. 2): 1, Sierra Bermeja: the most important outcrop, covering $319 \mathrm{~km}^{2}$ with an altitude range of between 50 and

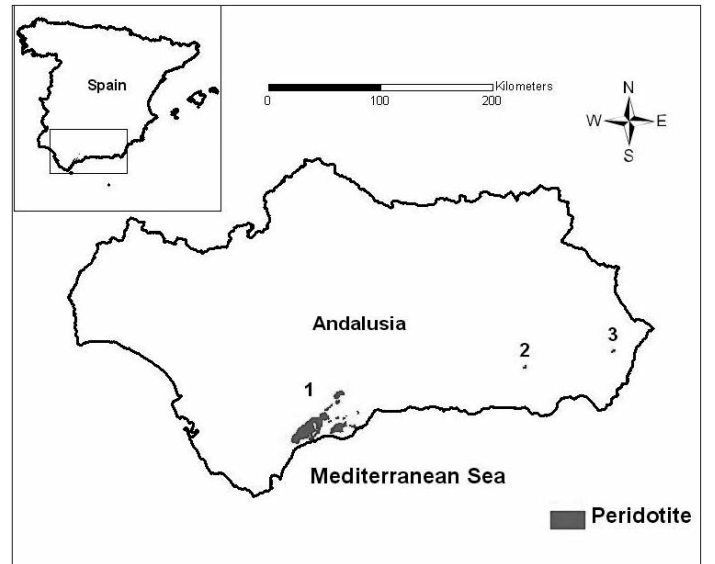

Fig. 1. Peridotite outcrops in Southern Iberian Peninsula (Andalusia, Spain): 1, Ronda Mountain ranges (Malaga); 2, Sierra Nevada (Almeria); 3, Lubrín (Almeria). Serpentinophytes are restricted to the outcrops of Malaga.

$1500 \mathrm{~m}$. 2, Sierra Alpujata: $71 \mathrm{~km}^{2}$ with an altitude range of between 140 and $1050 \mathrm{~m} .3$, Sierra de Aguas: $36 \mathrm{~km}^{2}$ and lying between 200 and $950 \mathrm{~m}$. 4, Sierras del Guadalhorce: small and isolated outcrops with a total area of $6 \mathrm{~km}^{2}$ and altitude range between 100 and $400 \mathrm{~m}$.

\section{Serpentinophytes checklist}

The list of species to be included as serpentinophytes has been created based in several sources. We follow the criteria used by Mota \& al. $(2008,2011)$ to select taxa associated with special substrata, among them, six were applied to establish the serpentinophyte checklist. These criteria were as follows. 1 , inductive: species observed on serpentine by our group since 1989 (Cabezudo \& al., 1989). 2, expertise: data taken from authors in the specialized literature and our own data that link taxa to serpentine. 3, bibliographical: individual taxa classified as serpentinophytes in the literature. 4, syntaxonomic: presence or absence of serpentinophytes in relevés and in syntaxa detected by others, such as Staehelino-Ulicion baetici, which are linked exclusively to serpentine. In addition, the 5

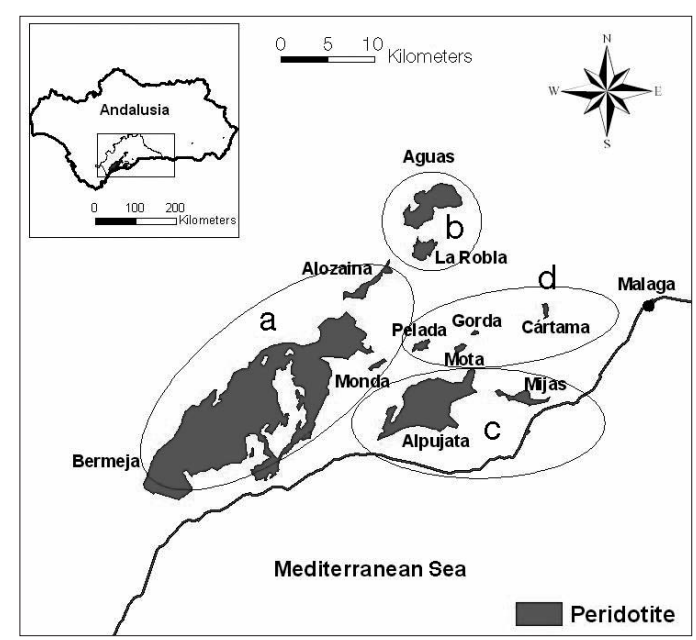

Fig. 2. Location and area of the peridotite outcrops in Malaga: a, Bermeja, $319 \mathrm{~km}^{2}$; b, Aguas, $35 \mathrm{~km}^{2}$; c, Alpujata, 71 km²; d, Guadalhorce, $6 \mathrm{~km}^{2}$. 


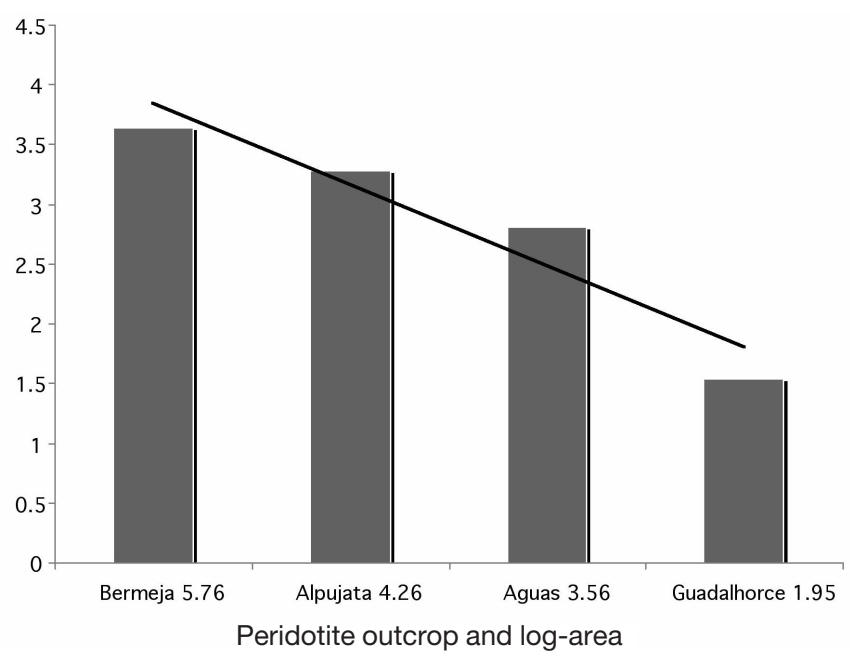

Fig. 3. Serpentinophyte richness correlated with the log-adjusted area of each peridotite outcrop (lineal adjust $R^{2}=0.9087$ ).

and 6 criteria (bio-indicator and edaphic) were used to propose three types of serpentinophytes depending whether some populations of the species may grow on other substrates.

First, a bibliographical search for species cited as possible serpentinophytes was made (Rivas Goday, 1974; López González, 1975; Rivas Goday \& López González, 1979; Castroviejo \& al., 1986-2011; Blanca \& al., 2011) and completed with chorological data obtained from GBIF (Global Biodiversity Information Facility in Spain) in 2011. To complete the data, a series of surveys in the peridotites of Malaga and Almeria (Fig. 1) were made (years 2009 to 2011), recording floristic (plant collecting), phenological, phytosociological (vegetation relevés), chorological (patterns of local distribution of populations) and ecological (habitat, altitude range, bioclimatic belt and rainfall range -ombrotype- Rivas Martínez, 2011) data. All the collected specimens were deposited in the University of Malaga Herbarium (MGC). Taking into account all the distributional data collected, the percentage of populations for each serpentinophyte known to grow on peridotites was estimated. This estimation was based on the number of geographically and/or ecologically separate localities for each population. Three categories of serpentinophily were described that were adapted from other categories used for plants living on soils such as dolomite and gypsum (Jeffrey, 1987; Mota \& al., 2008, 2011) and depended on the ecological and chorological affinity for peridotite and serpentine substrata. 1, obligate serpentinophytes: taxa linked exclusively to peridotite. 2, preferential serpentinophytes: at least $90 \%$ of populations linked to peridotites. 3, subserpentinophytes: at least $66 \%$ of populations linked to peridotites. We also considered some other species with a number of populations growing on peridotite, which may be regarded as subserpentinophytes following more exhaustive studies.

\section{Data provided about serpentinophytes}

The following data are provided for each taxon: scientific name, growth-form (Orshan, 1986), habitat, bioclimatic belt, altitude range, ombrotype, phytosociology, global and local distribution in the four geographic units described above, flowering/sporulation season (Roman numbers) and threat category (IUCN). Ecological data were mostly taken from Bañares \& al. (2003) and Blanca \& al. (1999-2000, 2011), with some data collected in situ as stated above. For the phytosociological nomenclature and syntaxonomy Pérez Latorre \& al. (1998), Rivas Martínez \& al. (2002) and Rivas Martínez (2011) were consulted and some vegetation inventories were made. Threat categories were taken from Andalusian (Blanca \& al., 1999, 2000; Cabezudo \& al., 2005), Spanish (Moreno, 2008) and European (Bilz \& al., 2011) red lists and conservation legislation. Serpentinophyte richness per outcrop (Fig. 3) was calculated as a function of a logarithm-adjusted area (Whittaker \& Fernández-Palacios, 2007; Pérez-García \& al., 2012). The botanical nomenclature follows Flora de Andalucia Oriental (Blanca \& al., 2011) unless otherwise indicated.

\section{RESULTS}

\section{Obligate serpentinophytes (Table1)}

\section{Allium rouyi Gaut.}

Geophyte with bulb. Lithosols. Thermomediterranean (150$700 \mathrm{~m}$ ). Subhumid-humid. Open shrublands, pastures and rocks (Staebelino-Ulicion baetici, Andryalo-Crambion filiformis and Phlomido-Brachypodietum retusi). Local endemism. Bermeja and Alpujata. VI-VII. CR (Spanish and Andalusian red lists), EN (Andalusian legislation) and LC (European red list). The taxonomic status and restricted distribution follow Cabezudo \& al. (1992) and Pastor \& al. (1995).

Alyssum serpyllifolium Desf. subsp. malacitanum Rivas Goday.

Chamaephyte / Hemicryptophyte multi-shooted. Slopes and rocky places. Thermo-meso-supramediterranean (50-1300 m). Dry-subhumid-humid. Scrublands and perennial pastures (Staehelino-Ulicion baetici, Andryalo-Crambion filiformis). Local endemism. Bermeja, Alpujata, Aguas and Guadalhorce. IIVI (VII). LC (Blanca \& al., 2011). This taxon should be considered as an amphiphyte (Orshan, 1986) as it presents two types of renewal buds. It has been reported as a nickel hyperaccumulator (Rufo \& al., 2004; Díez-Garretas \& al., 2009). Individuals with intermediate characters to those of subsp. serpyllifolium may be found in the proximity of serpentines on limestone and dolomitic sandstones (Blanca \& al., 2011).

\section{Arenaria capillipes Boiss.}

Therophyte. Lithosols. Meso-supramediterranean (800$1500 \mathrm{~m})$. Subhumid-humid-hyperhumid. Ephemeral pastures (Arenario capillipedis-Iberidetum fontqueri). Local endemism. Bermeja. IV-VI. NT (Spanish and Andalusian red lists), VU (Andalusian legislation).

\section{Armeria colorata Pau (Fig. 4d)}

Chamaephyte with rosettes. Screes, crevices and rocky 
Table 1. Presence and percentage above the total of obligate serpentinophytes in each peridotite outcrop in the south of the Iberian Peninsula. The relative frequency of obligate serpentinophytes in each outcrop follows the categories in Blanca \& al. (2011) adapted to the study area (rr, very rare; ra, rare; oc, occasional; fr, frequent).

\begin{tabular}{|c|c|c|c|c|}
\hline Taxon / Outcrop & Bermeja & Alpujata & Aguas & Guadalhorce \\
\hline Allium rouyi & $\mathrm{rr}$ & $\mathrm{rr}$ & - & - \\
\hline Alyssum serpyllifolium subsp. malacitanum & $\mathrm{fr}$ & $\mathrm{fr}$ & $\mathrm{fr}$ & oc \\
\hline Arenaria capillipes & ra & - & - & - \\
\hline Armeria colorata & $\mathrm{rr}$ & $\mathrm{rr}$ & - & - \\
\hline Armeria villosa subsp. carratracensis & $\mathrm{rr}$ & $\mathrm{rr}$ & ra & - \\
\hline Asplenium adiantum-nigrum var. corunnense & ra & - & - & - \\
\hline Bupleurum acutifolium & ra & - & - & ra \\
\hline Centaurea carratracensis & - & - & oc & - \\
\hline Centaurea haenseleri & ra & - & - & - \\
\hline Centaurea lainzii & $\mathrm{rr}$ & - & - & - \\
\hline Cephalaria baetica & oc & ra & - & - \\
\hline Euphorbia flavicoma subsp. giselae & $\mathrm{rr}$ & - & - & - \\
\hline Iberis fontqueri & oc & oc & ra & - \\
\hline Klasea baetica & $\mathrm{rr}$ & ra & $\mathrm{rr}$ & - \\
\hline Linum suffruticosum var. carratracensis & oC & oC & oc & - \\
\hline Notholaena marantae subsp. marantae & ra & ra & ra & - \\
\hline Peucedanum officinale subsp. brachyradium & $\mathrm{rr}$ & - & - & - \\
\hline Saxifraga gemmulosa & ra & $\mathrm{rr}$ & $\mathrm{rr}$ & - \\
\hline Silene fernandezii & ra & $\mathrm{rr}$ & - & - \\
\hline Silene inaperta subsp. serpentinicola & $\mathrm{rr}$ & $\mathrm{rr}$ & - & $\mathrm{rr}$ \\
\hline Staehelina baetica & $\mathrm{fr}$ & $\mathrm{fr}$ & oc & - \\
\hline Teucrium reverchonii & oc & oc & oc & - \\
\hline Obligate serpentinophytes per outcrop & 21 & 14 & 10 & 3 \\
\hline Obligate serpentinophytes per outcrop (\%) & 95 & 64 & 46 & 14 \\
\hline Outcrop area $\left(\mathrm{km}^{2}\right)$ & 319 & 71 & 36 & 6 \\
\hline
\end{tabular}

places on lithosols. Meso-supramediterranean (650-1500 m) Humid-hyperhumid. Perennial pastures and open scrublands (Andryalo-Crambion filiformis, Staebelino-Ulicion baetici). Local endemism. Bermeja and Alpujata. V-VII. EN (Spanish red list and Andalusian red list and legislation).

Armeria villosa Girard subsp. carratracensis (Bernis) Nieto Fel.

Chamaephyte with rosettes. Crevices, cliffs and slopes. Thermo-mesomediterranean (650-1300 m). Subhumid-humid. Perennial pastures and open scrublands (AndryaloCrambion filiformis, Staehelino-Ulicion baetici). Local endemism. Bermeja, Alpujata and Aguas. V-VII. EN (Spanish red list and Andalusian red list and legislation). A molecular, morphometric and experimental study established that this subspecies is hybrid taxon produced by the hybridization between the previous species and A. villosa subsp. longiaristata (Nieto Feliner \& al., 2002).

\section{Asplenium adiantum-nigrum L . var. corunnense H. Christ}

Hemicryptophyte with rosettes. Shaded and wet rock fissures. Meso-supramediterranean (1060-1410 m). Humid-hyperhumid. Umbrophilic rupicolous vegetation. (Asplenio corunnensis-Saxifragetum gemmulosae). Pen. Ibérica e Italia. Bermeja. (IV) V-X (XI). LC (Blanca \& al., 2011). The taxonomicl status given by Nogueira and Ormonde (1986) is adopted for this fern. In other floras, e.g. N Italy, this fern is considered as a preferential serpentinophyte (Selvi, 2007).

\section{Bupleurum acutifolium Boiss.}

Herbaceous chamaephyte. Rocky slopes and lithosols. Thermo-mesomediterranean (150-1200 m). Subhumid-humid. Shrublands (Staebelino-Ulicion baetici). Local endemism. Bermeja and Guadalhorce. VI-IX. VU (Spanish and Andalusian red lists).

\section{Centaurea carratracensis Lange (Fig. 4c)}

Erect hemicryptophyte. Lithosols and slopes. Thermo-mesomediterranean (300-950 m). Dry-subhumid. Shrublands, scrublands and slopes vegetation. (Staehelino-Ulicion baetici, Andryalo-Crambion filiformis). Local endemism. Aguas. (IV) V-VII. EN (Spanish and Andalusian red lists).

\section{Centaurea haenseleri Boiss. \& Reut.}

Hemicryptophyte with rosettes. Lithosols and rock fissures. Meso-supramediterranean (700-1500 m). Subhumidhumid-hyperhumid. Rupicolous vegetation (Andryalo-Crambion filiformis). Local endemism. Bermeja. V-VII. EN (Spanish and Andalusian red lists).

\section{Centaurea lainzii Fern. Casas}

Scapiform hemicryptophyte. Slopes and stony areas. Thermo-mesomediterranean (300-1100 m). Humid. Perennial pastures and shrublands (Andryalo-Crambion filiformis, Staebelino-Ulicion baetici). Local endemism. Bermeja. V-VII. CR (Spanish and Andalusian red lists). 


\section{Cephalaria baetica Boiss.}

Chamaephyte (scrub). Slopes and stony areas. Thermomesomediterranean (400-1100 m). Subhumid-humid-hyperhumid. Shrublands. (Andryalo-Crambion filiformis). Local endemism. Bermeja. VII-VIII (XI). NT (Spanish red list), EN (Andalusian red list).

\section{Euphorbia flavicoma DC. subsp. giselae Simon Pall.}

Chamaephyte. Lithosols. Thermo-mesomediterranean (500-1200 m). Humid-hyperhumid. Open forests (Pino pinastri-Quercetum cocciferae, Bunio macucae-Abietetum pinsapo). Local endemism. Bermeja. IV-VII. NT (Blanca \& al., 2011). The scarce populations in the Sierra Bermeja should be considered as an independent endemic taxon as they show some differences from the French populations (hair density and length; Simon Pallisé, 1997). Other differential characters that we observed are related to leaf size and margin.

\section{Iberis fontqueri Pau}

Fasciculate therophyte. Slopes, stony places and lithosols. Thermo-mesomediterranean (200-1100 m). Subhumid-humid. Ephemeral pastures. (Arenario-capillipedis-Iberidetum fontqueri). Local endemism. Bermeja, Alpujata and Aguas. III-VI. VU (Spanish and Andalusian red lists).

\section{Klasea baetica (Boiss.) Holub}

Scapiform hemicryptophyte. Stony soils. Thermo-mesosupramediterranean (300-1400 m). Subhumid-humid-hyperhumid. Shrublands (Staebelino-Ulicion baetici). Local endemism. Bermeja and Aguas. IV-VI. EN (Spanish and Andalusian red lists). Blanca \& al. (2011) mention this taxon as a Betic-Rifean species. However, we were unable to find any record for the Rif mountains (Morocco) and it is absent from the "Checklist of Vascular Plants of Northern Morocco" (Valdés \& al., 2002).

Linum suffruticosum L. var. carratracensis (Rivas Goday \& Rivas Mart.) G. López

Chamaephyte (scrub). Stony slopes. Thermo-mesomediterranean (340-1200 m). Subhumid-humid. Shrublands and perennial pastures. (Staehelino-Ulicion baetici, AndryaloCrambion filiformis). Local endemism. Bermeja, Alpujata and Aguas. V-VII. LC (Blanca \& al., 2011).

\section{Notholaena marantae (L.) Desv. subsp. marantae (Fig. 4a)}

Hemicryptophyte with rosettes. Rock fissures and stony slopes. Thermomediterranean (350-700 m). Subhumid-humid. Rupicolous perennial pastures. (Notholaeno marantaeCheilanthetum guanchicae). Circum-Mediterranean, East Africa and Himalaya. Bermeja, Alpujata and Aguas. (II-VI). LC (Blanca \& al., 2011). In the north Italian flora it is considered as a preferential serpentinophyte (Selvi, 2007).

Peucedanum officinale L. subsp. brachyradium García Martín \& Silvestre

Erect hemicryptophyte. Slopes. Thermomediterranean
(800-900 m). Humid. Pine woods and kerm-oak shrublands (Pino pinastri-Quercetum cocciferae). Local endemism. Bermeja. IX-X. CR (Spanish and Andalusian red lists).

\section{Saxifraga gemmulosa Boiss.}

Cushion hemicryptophyte. Fissures of rocky shaded places and slopes. Thermo-meso-supramediterranean (560-1410 m). Subhumid-humid-hyperhumid. Umbrophilic rupicolous vegetation (Asplenio corunnensis-Saxifragetum gemmulosae, Selaginello denticulatae-Saxifragetum gemmulosae). Local endemism. Bermeja, Alpujata and Aguas. IV-VI. VU (Spanish and Andalusian red lists). It has been described as a nickel hyper-accumulator (Rufo \& al., 2004; Díez-Garretas \& al., 2009).

Silene inaperta L. subsp. serpentinicola Talavera

Erect therophyte. Stony slopes and lithosols. Thermo-mesomediterranean (200-1000 m). Dry-subhumid-humid. Ephemeral pastures. (Omphalodion commutatae). Local endemism. Bermeja, Alpujata and Guadalhorce. V-VII. EN (Spanish and Andalusian red lists).

\section{Silene fernandezii Jeanmonod}

Herbaceous chamaephyte. Slopes, rock fissures and stony ground. Thermo-meso-supramediterranean (600-1500 m). Subhumid-humid-hyperhumid. Rupicolous vegetation. (Andryalo-Crambion filiformis). Local endemism. Bermeja and Alpujata. V-VI (VII). EN (Spanish and Andalusian red lists; Andalusian legislation).

\section{Staehelina baetica DC. (Fig. 4b)}

Chamaephyte (scrub-like to cushioned). Stony slopes and lithosols. Thermo-meso-supramediterranean (300-1400 m). Subhumid-humid-hyperhumid. Shrublands. (Staehelino-Ulicion baetici). Local endemism. Bermeja, Alpujata and Aguas. V-VII. LC (Blanca \& al., 2011).

\section{Teucrium reverchonii Willk.}

Chamaephyte. Stony slopes and lithosols. Thermo-mesomediterranean (300-1200 m). Dry-subhumid. Shrublands. (Staebelino-Ulicion baetici). Local endemism. Bermeja, Alpujata and Aguas. V-VI (VII). NT (Blanca \& al., 2011).

\section{Preferentialserpentinophytes}

\section{Galium boissieranum (Steud.) Ehrend. \& Krendl}

Herbaceous chamaephyte. Stony slopes. Thermo-mesosupramediterranean (300-1500 m). Subhumid-humid. Shrublands (Staebelino-Ulicion baetici). Local endemism. Bermeja, Alpujata and Aguas. (IV) V-VII (IX). VU (Spanish and Andalusian red lists). About $90 \%$ of its populations grow on peridotites and the rest on dolomites, as occurs in Sierra Blanca de Ojen (Malaga) and Sierra de Grazalema (Cadiz).

Galium viridiflorum Boiss. \& Reut. (Fig. 4e)

Scandent chamaephyte. Streams and wet soils. Thermomesomediterranean (100-1200 m). Subhumid-humid. Wet 

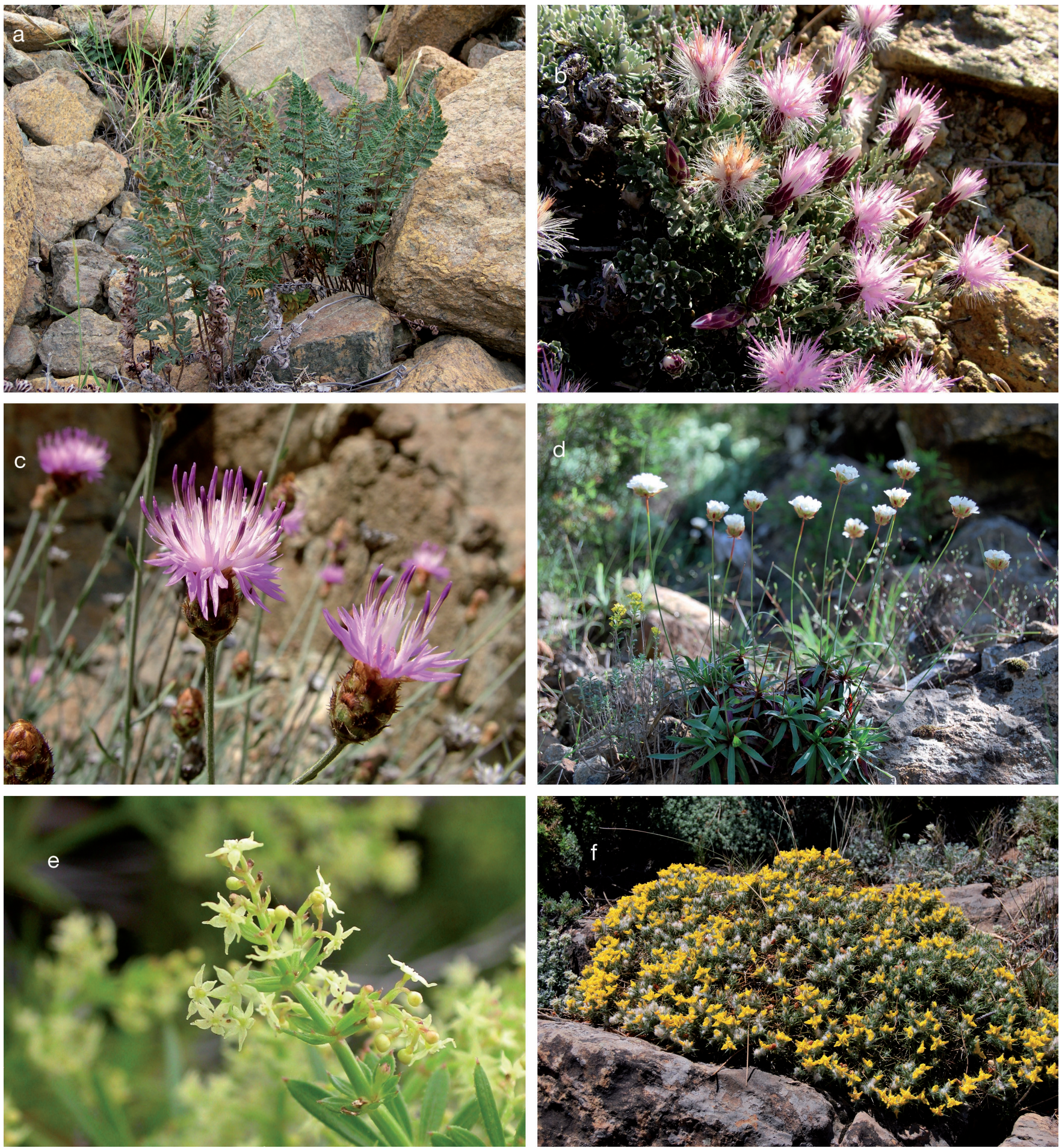

Fig. 4. Some selected South-Iberian serpentinophytes. Obligate serpentinophytes: a, Notholaena marantae (Sinopteridaceae); b, Staehelina baetica (Asteraceae); c, Centaurea carratracensis (Asteraceae); d, Armeria colorata (Plumbaginaceae). Preferential serpentinophytes: e, Galium viridiflorum (Rubiaceae). Subserpentinophytes: f, Genista hirsuta subsp. lanuginosa (Fabaceae). (Photographs: a, d, f, A.V. Pérez-Latorre; b, c, M. Becerra; e, F. Casimiro-Soriguer).

grasslands, hydrophilic vegetation and riverine forests. (Galio viridiflori-Schoenetum nigricantis, Molinio-Ericetum erigenae, Erico-Nerietum oleandri, Erico-Salicetum pedicellatae). Local endemism. Bermeja, Alpujata and Aguas. V-VII (VIII). VU (Spanish and Andalusian red lists and Andalusian legisla- tion), special protection status (Spanish legislation), EN (European red list). It is the only serpentinophyte of our list included in Annex II of the "Habitats" Directive 92/43EU. There are scarce populations in Tejeda-Almijara ranges (Malaga-Granada) on dolomitic soils. 


\section{Subserpentinophytes}

\section{Arenaria retusa Boiss.}

Erect therophyte. Stony slopes and lithosols. Thermo-mesomediterranean (150-1000 m). Subhumid-humid. Ephemeral pastures. (Omphalodion commutatae). Local endemism. Bermeja, Alpujata and Aguas. III-VI. LC (Blanca \& al., 2011). Some populations inhabit dolomites in the north of Ronda and Grazalema mountain ranges (Malaga and Cadiz provinces) and calcareous sandstones in the north of Malaga province.

\section{Genista hirsuta Vahl subsp. lanuginosa (Spach) Nyman (Fig.} 4f)

Cushion chamaephyte / nanophanerophyte (shrub). Slopes and lithosols. Thermo-mesomediterranean (50-1300 m). Subhumid, humid, hyperhumid. Shrublands (StaehelinoUlicion baetici). Bermeja, Alpujata and Aguas. III-VI (VII). LC (Blanca \& al., 2011). Some populations inhabit micaschists and gneiss in Ronda mountain range (Malaga province), Chipiona (Cadiz province) and Xauen (Rif, north Morocco). We agree with Talavera (1999) with regard to the differential characters of the serpentinicolous populations, to which we add a reduced number of leaves and distance between thorns, and denser pubescence. These populations should be included in the obligate serpentinophyte group if assigned a taxonomic status.

\section{Senecio eriopus Willk. subsp. eriopus}

Hemicryptophyte with rosettes. Stony slopes. Thermo-mesomediterranean (500-1300 m). Subhumid-humid-hyperhumid. Shrublands (Staehelino-Ulicion baetici). Local endemism. Bermeja and Alpujata. V-VI. NT (Blanca \& al., 2011). It also grows on dolomites, sandstones and marbles in Ronda and Grazalema mountain ranges (Malaga and Cadiz provinces) and in the Alpujarras region (Granada province).

\section{Otherimportant species}

Digitalis obscura L. subsp. laciniata (Lindl.) Maire grows mainly on peridotites and secondarily on dolomites and sandstones in Andalusia and Morocco. Elaeoselinum asclepium (L.) Bertol. subsp. millefolium (Boiss.) García Martín and Silvestre is endemic to the south of the Iberian Peninsula, where it mainly inhabits peridotites, although it can also be found on sandstones and dolomites. Both taxa nearly reach the limit percentage for serpentine populations to be considered as subserpentinophytes. Avenula gervaisii Holub subsp. gervaisii and Scorzonera baetica (Boiss.) Boiss. have approximately $50 \%$ of the populations growing on serpentines.

Bupleurum foliosum Salzm. ex DC., Polygala baetica Willk., Rubia agostinhoi Dans. \& P. Silva, Festuca lasto Boiss. and Silene scabriflora Brot. subsp. tuberculata (Ball) Talavera are very restricted species that only inhabit the Strait of Gibraltar phytogeographical area (south-western Andalusia and northern Morocco) on sandstones and siliceous soils. Some populations reach Sierra Bermeja peridotites and so a biogeographical connection may be supposed.
Halimium atriplicifolium (Lam.) Spach. subsp. serpentinicola Rivas Goday and Rivas-Martínez does not show any differences from $H$. atriplicifolium subsp. atriplicifolium (Nogueira \& al., 1993; Morales Torres, 2009). Most of its populations could be considered as magnesicolous (peridotites and dolomites).

\section{DISCUSSION}

Except for Asplenium adiantum-nigrum var. corunnense and Notholaena marantae, the south Iberian serpentinophytes are considered as Mediterranean floristic elements (Blanca \& al., 2011), showing eco-morphological and functional adaptations to the characteristic dry period of the Mediterranean climate (Orshan, 1986). Xeromorphic adaptations and a predominantly spring flowering season (Pérez Latorre \& Cabezudo, 2002) are regarded as relevant factors for colonizing Mediterranean peridotites (Chiarucci, 2003). One exception worthy of note is Peucedanum officinale subsp. brachyradium with its autumn-flowering.

The chorological spectrum of south Iberian serpentinophytes reflects their affinity for the peridotite outcrops of Malaga province, grouped in the Bermejense phytogeograhical sector (Nieto \& al., 1991). Most of the obligate serpentinophytes (20) are local endemisms except for Asplenium adiantum-nigrum var. corunnense and Notholaena maranthae, which have a wider distribution. The endemicity rate for obligate serpentinophytes is $91 \%$. The two preferential serpentinophytes (Galium boissieranum and G. viridiflorum) are also restricted endemisms from Malaga, Cádiz and Granada provinces. Two of the subserpentinophytes (Arenaria retusa and Senecio eriopus) are restricted endemisms of Malaga and Cádiz (Senecio is also present in Granada), as is Genista hirsuta subsp. lanuginosa but this taxon reaches Morocco. $74 \%$ of the serpentinophytes are local endemisms and this percentage reaches $89 \%$ if an area centered in Malaga province and surroundings is considered.

As was found with Italian peridotite outcrops (Selvi, 2007), the number of obligate serpentinophytes in Andalusia increases with the outcrop area (Table 1). Serpentinophyte richness (Fig. 3) increases with that of the log-correlated area of the outcrops (lineal adjust $\mathrm{R}^{2}=0.9087$ ). Sierra Bermeja shows the highest richness (3.64) and is the only outcrop where all the serpentinophytes, except Centaurea carratracensis, are found. This mountain range enjoys a high protection status at both regional (Natural Site) and European (LIC) levels. Guadalhorce is the smallest outcrop and shows the lowest richness (1.54).

Serpentinophytes and dolomitophytes in Andalusia (Mota \& al., 2008) show a very similar spectrum of biological types (Table 2). Hemicryptophytes (33.3\%) and chamaephytes $(44.4 \%)$ dominate on peridotites, while geophytes and phanaerophytes are nearly absent. This result coincides with findings for peridotites in northern Italy (Selvi, 2007).

In contrast, the taxonomic spectrum for obligate serpentinophytes (Table 3) and dolomitophytes (Mota \& al., 2008) show several differences. Fabaceae and Scrophulariaceae, both absent from the group of obligate serpentinophytes, are the best represented families amongst dolomitophytes, whereas members of Brassicaceae, Caryophyllaceae 
Table 2. Comparison of the percentage of growth-forms between serpentinophytes and dolomitophytes sensu Mota \& al. (2008). Growthforms follow Orshan's classification (amphiphyte: two growth forms in the plant).

\begin{tabular}{lcc}
\hline Growth form & Serpentinophytes & Dolomitophytes \\
\hline Therophyte & 14.8 & 13.9 \\
Geophyte & 3.7 & rare \\
Hemicryptophyte & 33.3 & 48.6 \\
Chamaephyte & 44.4 & 36.1 \\
Amphiphyte & 3.7 & - \\
\hline
\end{tabular}

and Lamiaceae are frequent in both edaphic types. The family Asteraceae has the highest number of serpentinophyte species. Worthy of note is the lack of serpentinophytes among the family Poaceae, as also occurs in eastern Greek peridotites (Trigas \& Iatrou, 2006) but not in north Italian outcrops (Selvi, 2007).

The most representative genera in the serpentine flora of Andalusia and Portugal (Menezes \& Pinto da Silva, 1992) are Alyssum, Arenaria, Armeria, Asplenium, Centaurea and Silene. Genera common to Italian (Selvi, 2007) and Andalusian peridotite flora are Alyssum, Armeria, Centaurea and Euphorbia. Alyssum, Centaurea and Silene are common among Greek (Trigas \& Iatrou, 2006) and Andalusian peridotites, while only Alyssum and Silene are common among Turkish (Reeves \& Adigüzel, 2004) and Andalusian peridotites. Notholaena marantae and Digitalis obscura subsp. laciniata are the only serpentinicolous taxa common to Moroccan (Ater \& al., 2000) and Andalusian peridotites.

When comparing Iberian serpentine endemics with other ultramafic Mediterranean areas in the world such as California (Kruckeberg, 1992; Safford \& al., 2005), of particular note are the dominance of Brassicaceae and Liliaceae in Cali-

Table 3. Number and percentage of serpentinophytes indexed by families.

\begin{tabular}{cc}
\hline Family & Species (\%) \\
\hline Obligate serpentinophytes & \\
Asteraceae & $5(23)$ \\
Caryophyllaceae & $3(14)$ \\
Apiaceae & $2(9)$ \\
Brassicaceae & $2(9)$ \\
Plumbaginaceae & $2(9)$ \\
Alliaceae & $1(5)$ \\
Aspleniaceae & $1(5)$ \\
Dipsacaceae & $1(5)$ \\
Euphorbiaceae & $1(5)$ \\
Lamiaceae & $1(5)$ \\
Linaceae & $1(5)$ \\
Saxifragaceae & $1(5)$ \\
Sinopteridaceae & $1(5)$ \\
Preferential serpentinophytes & \\
Rubiaceae & $2(100)$ \\
Subserpentinophytes & \\
Caryophyllaceae & $1(33)$ \\
Fabaceae & $1(33)$ \\
Asteraceae & $1(33)$ \\
\hline
\end{tabular}

fornia (Asteraceae in the Iberian Peninsula), the presence of Galium and Allium as common serpentinophyte genera, the very few endemics among the Poaceae (none in the Iberian Peninsula), and the coincidence of bodenvag forest genera (Pinus jeffrey and Quercus vaccinifolia in California and Pinus pinaster and Quercus coccifera in the Iberian Peninsula).

Centaurea prolongi Boiss., Hormathophylla longicaulis (Boiss.) Cullen \& T.R. Dudley, Linaria saturejoides Boiss., Omphalodes commutata G. López and Ulex baeticus Boiss. s.l. are considered as dolomitophytes by Mota \& al. (2008) but they can also be found growing on peridotite, so we prefer to consider them as magnesicolous species. While Alyssum serpyllifolium s.l. (subsp. malacitanum for this work), Armeria villosa subsp. carratracensis and Iberis fontqueri appear as dolomitophytes in Mota \& al. (2008), the data obtained in the present study indicate that they should be considered as obligate serpentinophytes.

Most serpentinophytes present a wide bioclimatic range, as they may inhabit two or more bioclimatic belts (24 taxa, 89\%) or two or more ombrotypes (25 taxa, $93 \%$ ). Alyssum malacitanum, Genista lanuginosa $(1250 \mathrm{~m})$ and Galium boissieranum $(1200 \mathrm{~m})$ show the widest altitudinal interval, while Peucedanum brachyradium $(100 \mathrm{~m})$ and Notholaena marantae and Asplenium corunnense $(350 \mathrm{~m})$ show the narrowest interval. Only 10 taxa $(37 \%)$ reach the supramediterranean bioclimatic belt (the least extensive), while the thermo and mesomediterranean belts are equally rich in serpentinophytes., although Allium rouyi, Notholaena marantae and Peucedanum brachyradium are restricted to the thermomediterranean bioclimatic belt. Alyssum malacitanum, Centaurea carratracensis, Teucrium reverchonii and Silene serpentinicola should be considered as the most xero-thermophilous taxa since they are the only ones that inhabit the thermomediterranean belt with its dry ombrotype.

The habitats and plant communities preferred by the serpentinophytes are shrublands on poorly developed soils (Staebelino-Ulicion baetici alliance in Cisto-Lavanduletea class) and the communities living on slopes, lithosols and rock fissures (alliance Andryalo-Crambion filiformis, class Phagnalo-Rumicetea indurati) (Table 4). These types of communities are the ones with the highest endemicity rate among Mediterranean habitats (Snoguerup, 1971; Gómez-Campo, 1985; Médail \& Verlaque, 1997). However, one species, Galium viridiflorum stands out because it is the only serpentinophyte associated with wet ecosystems. This pattern is also found in serpentinicolous vegetation of northern Portugal and south Iberia, which shows similar trends, both being abundant in shrublands and rupicolous plant communities (Menezes \& Pinto da Silva, 1992).

According to the Spanish Red List of endangered species (Moreno, 2008), the percentage of obligate serpentinophytes threatened is $59 \%$ (13 taxa), of which $45 \%$ (10 taxa) are included in the two high risk categories (CR and EN) and 15\% ( 3 taxa) are classified as VU. If we consider all the serpentinophytes (27 taxa), 56\% are threatened (15 taxa). A study carried out in northern Italian peridotites revealed that among 11 obligate serpentinophytes only one is considered as EN at a regional level (Selvi, 2007).

It is clear that adaptation to serpentine substrate is one of 
Table 4. Number of serpentinophytes appearing in each syntaxon and its habitat. O, obligate; P, preferential; S, subserpentinophyte. (*): Galio viridifloriSchoenetum nigricantis, Molinio arundinaceae-Ericetum erigenae, Erico terminalis-Nerietum oleandri, Erico erigenae-Salicetum pedicellatae.

\begin{tabular}{|c|c|c|c|c|}
\hline \multirow[t]{2}{*}{ Syntaxon } & \multirow[t]{2}{*}{ Habitat/vegetation } & \multicolumn{3}{|c|}{ Serpentinophytes } \\
\hline & & $\mathbf{O}$ & $\mathbf{P}$ & $\mathbf{S}$ \\
\hline Staehelino-Ulicion baetici & xerophytic shrublands & 11 & 1 & 2 \\
\hline Andryalo-Crambion filiformis & stony slopes & 10 & - & - \\
\hline Asplenio corunnensis-Saxifragetum gemmulosae & fissures of shaded rocks & 2 & - & - \\
\hline Arenario capillipedis-Iberidetum fontqueri & lithosols & 2 & - & - \\
\hline Pino pinastri-Quercetum cocciferae & tall shrublands with pines & 2 & - & - \\
\hline Omphalodion commutatae & sandy lithosols & 1 & - & 1 \\
\hline Bunio macucae-Abietetum pinsapo & fir forests & 1 & - & - \\
\hline Notholaeno marantae-Cheilanthetum guanchicae & fissures in sunny rocks & 1 & - & - \\
\hline Phlomido lychnitidis-Brachypodion retusi & xerophytic pastures & 1 & - & - \\
\hline Selaginello denticulatae-Saxifragetum gemmulosae & shaded, slight slopes with clay & 1 & - & - \\
\hline Higrophilous communities (*) & springs and streams & - & 1 & - \\
\hline
\end{tabular}

the main sources od endemicity, and therefore of plant diversity. Due to the exceptional nature of the vegetation and flora that are found therein, which is underlined by the results of this work, the biggest of the Andalusian peridotite outcrops (Sierra Bermeja) has been proposed as National Park, the maximum protection category for natural spaces in Spain. These areas are the same as those proposed by Médail \& Diadema (2009) as a phylogeographical refuge and a "hot-spot" in the context of the Mediterranean Basin (5. Serrania de Ronda), and overlap an important area for threatened Spanish flora (Bañares \& al., 2003).

\section{ACKNOWLEDGEMENTS}

We thank the editor and the two reviewers for useful comments and suggestions that have improved the work. N. Hidalgo Triana has been supported by two scholarships (0906 and 0921) of the University of Malaga (UMA). We thank the Andalusian Government for granting us permission to work in the protected areas ( $\mathrm{Pj} \mathrm{SB} / \mathrm{AU} / 03-2011)$. We are grateful to F. Casimiro-Soriguer and M. Becerra Parra for the use of their photographs.

\section{REFERENCES}

Alados, C.L., Navarro, T. \& Cabezudo, B. 1999. Tolerance assessment of Cistus ladanifer to serpentine soils by developmental stability. Plant Ecology 143 (1): 51-66

Ater, M., Lefèbvre, C., Gruber, W. \& Meerts, P. 2000. A phytogeochemical survey of the flora of ultramafic and adjacent normal soils in North Morocco. Plant Soil 218: 127-135.

Bañares, A., Blanca, G., Güemes, J., Moreno, J.C. \& Ortiz, S. 2003. Atlas y Libro Rojo de la Flora Vascular Amenazada de España. Dirección General de Conservación de la Naturaleza y Sociedad Española de Biología de la Conservación de Plantas, Madrid.

Bilz, M., Kell, S.P., Maxted, N. \& Lansdown, R.V. 2011. European Red List of Vascular Plants. Publications Office of the European Union, Luxembourg.

Blanca, G., Cabezudo, B., Hernández-Bermejo, J.E., Herrera, C.M., Molero Mesa, J., Muñoz, J. \& Valdés, B. 1999-2000. Libro rojo de la flora silvestre amenazada de Andalucía. Junta de Andalucía, Sevilla.

Blanca, G., Cabezudo, B., Cueto, M., Morales Torres, C. \& Salazar, C. 2011. Flora Vascular de Andalucía Oriental (2 ${ }^{\mathrm{a}}$ Edición). Consejería de Medio Ambiente, Junta de Andalucía, Sevilla.

Brady, K.U., Kruckeberg, A.R. \& Bradshaw, H.D. 2005. Evolutionary ecology of plant adaptation to serpentine soils. Annual Review of Ecology, Evolution, and Systematics 36: 243-266.

Brooks, R., 1987. Serpentine and its vegetation. A multidisciplinary approach. Dioscorides Press. Portland.

Cabezudo, B., Nieto-Caldera, J.M. \& Pérez-Latorre, A.V. 1989. Contribución al conocimiento de la vegetación edafófilo-serpentinícola del sector Rondeño (Málaga; España). Acta Botanica Malacitana 14: 291-294.
Cabezudo, B. Pastor, J., Trigo, M. M. \& Nieto, J. M. 1992. Observaciones sobre Allium rouyi Gautier. Acta Botanica Malacitana 17: 123-126.

Cabezudo, B., Talavera, S., Blanca, G., Salazar, C., Cueto, M., Valdés, B., Hernández Bermejo, J.E., Herrera, C.M., Rodríguez Hiraldo, C. \& Navas, D. 2005. Lista Roja de la flora vascular de Andalucía. Consejería de Medio Ambiente, Junta de Andalucía, Sevilla.

Castroviejo, S. \& al. 1986-2012. Flora Iberica. Real Jardín Botánico, CSIC. Madrid.

Chiarucci, A. 2003. Vegetation ecology and conservation on Tuscan ultramafic soils. Botanical Review 69(3): 252-268.

Díez-Garretas, B., Asensi, A., Rufo, L., Rodríguez, N., Sánchez-Mata, D., Amils, R. \& de la Fuente, V. 2009. Saxifraga gemmulosa Boiss. (Saxifragaceae), an endemic nickel bioindicator from ultramafic areas of the Southern Iberian Peninsula. Northeastern Naturalist 16: 56-64.

Gómez-Campo, C. 1985. The conservation of Mediterranean plants: principles and problems. In: Gómez-Campo, C. (ed.), Plant conservation in the Mediterranean area. Dr. W. Junk. Dordrecht.

IGME (Instituto Geológico-Minero de España). 1970. Mapa geológico de España 1:200.000. Algeciras (4-12). Madrid.

IGME (Instituto Geológico-Minero de España). 1981. Mapa geológico de España 1:200.000. Morón de la Frontera (4-11). Madrid.

Jeffrey, D.W. 1987. Soil-plant relationships: an ecological approach. Timber Press. Portland.

Kruckeberg, A. 1992. Plant life of western North American ultramafics. In: Roberts, B.A. \& Proctor, J. (eds.), The ecology of areas with serpentinized rocks. A world view. Kluwer Academic Publishers. Dordrecht.

Kruckeberg, A. 2002. Geology and plant life. University Press. Washington. López González, G. 1975. Contribución al estudio florístico y fitosociológico de Sierra de Aguas. Acta Botanica Malacitana 1: 81-205.

Médail, F. \& Verlaque, R. 1997. Ecological characteristics and rarity of endemic plants from southeast France and Corsica: implications for biodiversity conservation. Biological Conservation 80: 269-281.

Médail, F. \& Diadema, K. 2009. Glacial refugia influence plant diversity patterns in the Mediterranean basin. Journal of Biogeography 36: 1333-1345.

Menezes, E. \& Pinto Da Silva, A.R. 1992. Ecology of serpentinized areas of north-east Portugal. In: Roberts, B.A. \& Proctor, J. (eds), The ecology of areas with serpentinized rocks. A world view. Kluwer Academic Publishers. Dordrecht.

Morales Torres, C. 2009. Halimium (Dunal) Spach. In: Blanca, G \& al. (eds.), Flora Vascular de Andalucia Oriental 3: 189. Consejería de Medio Ambiente, Junta de Andalucía, Sevilla.

Moreno, J.C. (coord.) 2008. Lista Roja de la Flora Vascular Española. Dirección General del Medio Natural y Política Forestal. Ministerio de Medio Ambiente y Medio Rural y Marino y Sociedad Española de Biología de la Conservación de Plantas, Madrid.

Mota, J.F., Medina-Cazorla, J.M., Bruno, F., Pérez-García, F.J., Pérez-Latorre, A.V., Sánchez-Gómez, P., Torres, J.A., Benavente, A., Blanca, G., Gil de Carrasco, C., Lorite, J. \& Merlo, M.E. 2008. Dolomite flora of the Baetic Ranges glades (South Spain). Flora 203:359-375.

Mota, J.F., Sánchez-Gómez, P. \& Guirado, J.S. 2011. Diversidad vegetal de las yeseras ibéricas. ADIF y Mediterráneo. Sevilla. 
Muñoz Garmendia, F. \& Navarro, C. 1993. Halimium (Dunal) Spach. In Castroviejo, S. \& al. (eds.), Flora iberica 3: 343. Real Jardín Botánico, CSIC. Madrid.

Nieto, J., Pérez-Latorre, A.V. \& Cabezudo, B. 1991. Biogeografía y series de vegetación de la provincia de Málaga (España). Acta Botanica Malacitana 16(2): 417-436.

Nieto, Feliner, G., Fuertes Aguilar, J. \& Rosselló J.A. 2002. Reticulation or divergence: the origin of a rare serpentine endemic assessed with chloroplast, nuclear and RAPD markers. Plant Systematics and Evolution 231: 19-38.

Nogueira, I. \& Ormonde, J. 1986. Asplenium L. In: Castroviejo, S. \& al. (eds), Flora iberica 1: 102. Real Jardín Botánico, CSIC. Madrid.

Nogueira, I., Muñoz Garmedia, F. \& Navarro, C. 1993. Halimium (Dunal) Spach. In: Castroviejo, S., \& al. (eds), Flora iberica 3: 343. Real Jardín Botánico, CSIC. Madrid.

Orshan, G. 1986. Plant form as describing vegetation and expressing adaptation to environment. Annali di Botanica 44: 7-38.

Pastor, J.E., Diosdado, J.C. \& Cabezudo, B. 1995. A karyological study of Allium rouyi Gautier (Liliaceae), a recently rediscovered endemic species from the south of Spain. Botanical Journal of the Linnean Society 117: 255 258.

Pérez-García, F.J., Medina-Cazorla, J.M., Martínez-Hernández, F., GarridoBecerra, J.A., Mendoza-Fernández, A.J., Salmerón-Sánchez, E. \& Mota, J.F. 2012 Iberian Baetic endemic flora and the implications for a conservation policy. Annales Botanici Fennici 49: 43-54.

Pérez-Latorre, A.V., Navas, P., Navas, D., Gil, Y. \& Cabezudo, B. 1998. Datos sobre la flora y vegetación de la Serranía de Ronda (Málaga, España). Acta Botanica Malacitana 23: 149-191.

Pérez-Latorre, A.V. \& Cabezudo, B. 2002. Use of monocharacteristic growth forms and phenological phases to describe and differentiate plant communities in Mediterranean-type ecosystems. Plant Ecology 161(2): 231249.

Pichi-Sermolli, R.E.G. 1948. Flora e vegetazione delle serpentine e delle altre ofiolita dell'Alta valle del Tevere. Webbia 6: 1-378.

Reeves, R. \& Adigüzel, N. 2004. Rare plants and nickel accumulators from Turkish serpentine soils, with special reference to Centaurea species. Turkish Journal of Botany 28: 147-153.

Rivas Goday, S. 1974. Edafismos ibéricos de rocas ultrabásicas y dolomíticas: interpretación biogeoquímica y sus posibles correlaciones cariológicas. Las Ciencias 39: 66-73.

Rivas Goday, S. \& López González, G. 1979. Nuevos edafismos hispánicos de substratos ultrabásicos y dolomíticos. Anales de la Real Academia de Farmacia 45: 95-112.

Rivas Martínez, S. 2011. Mapa de series, geoseries y geopermaseries de vegetación de España. Itinera Geobotanica 18(1): 5-424.
Rivas-Martínez, S., Díaz, T.E., Fernández Gonzalez, F., Izco, J., Loidi, J., Lousa, M. \& Penas, A. 2002. Vascular plant communities of Spain and Portugal. Addenda to the syntaxonomical checklist of 2001. Itinera Geobotanica 15(1, 2): 1-922.

Roberts, B.A. \& Proctor, J. 1992. The ecology of areas with serpentinized rocks. A world view. Kluwer academic publishers. Dordrecht.

Rufo, N., García, V., Sánchez-Mata, D. \& Rodríguez-Rojo, M. 2004. Studies on Iberian Peninsula ultramafic flora: a selected nickel accumulation screening. Lazaroa 25: 161-167.

Rune, O. 1953. Plant life on serpentines and related rocks in the north of Sweden. Acta Phytogeographica Suecica 31: 1-139.

Safford, H.D., Viers, J.H. \& Harrison, S.P. 2005. Serpentine endemism in the California flora: a database of serpentine affinity. Madroño 52(4): 222 257.

Selvi, F. 2007. Diversity, geographic variation and conservation of the serpentine flora of Tuscany (Italy). Biodiversity and Conservation 16: 1423 1439.

Simon Pallisé, J. 1997. Una nueva subespecie para Euphorbia flavicoma DC. (Euphorbiaceae). Anales del Jardín Botánico de Madrid 55(1): 199-200.

Snogerup, S. 1971. Evolutionary and plant geographical aspects of chasmophytic communities. In: Davis, P.H., Harper, P.C. \& Hedge, I.C. (eds.), Plant Life of South-West Asia. Botanical Society of Edinburgh, Edinburgh.

Stevanovič, V., Tan, K. \& Iatrou, G. 2003. Distribution of endemic Balkan flora on serpentine. I. Obligate serpentine endemics. Plant Systematics and Evolution 242: 149-170.

Talavera, S. 1999. Genista L. In: Castroviejo, S. \& al. (eds.) Flora iberica 7: 110. Real Jardín Botánico, CSIC. Madrid.

Trigas, P. \& Iatrou, G. 2006. The local endemic flora of Evvia (W Aegean, Greece). Willdenowia 36: 257-270.

Valdés, B., Rejdali, M., Achhal, A., Jury, S.L. \& Montserrat, J.M. 2002. Checklist of vascular plants of N Morocco with identification keys. CSIC. Madrid.

Whittaker, R.H. 1954. The ecology of serpentine soils. Ecology 35: 258-288.

Whittaker, R.J. \& Fernández-Palacios, J.M. 2007. Island biogeography, ecology, evolution, and conservation, 2nd edn. Oxford University Press. Oxford.

Yusta, A., Berahona, E., Huertas, F., Reyes, E., Yáñez, J. \& Linares, J. 1985. Geochemistry of soils from peridotite in Los Reales, Málaga. Mineralogy and Petrography Acta 29-A: 439-498.

Associate Editor: Juan F. Mota Received: 6-XI-2012 Accepted: 26-IV-2013 